https://doi.org/10.15407/ujpe63.4.362

T. GAVRILKO,${ }^{1}$ V. NECHYTAYLO,${ }^{1}$ L. VIDUTA,${ }^{1}$ J. BARAN ${ }^{2}$

${ }^{1}$ Institute of Physics, Nat. Acad. of Sci. of Ukraine

(46, Prosp. Nauky, Kyiv 03028, Ukraine; e-mail: gavrilko@gmail.com)

${ }^{2}$ Institute of Low Temperatures and Structure Research, PAN

(2, Okolna Str., 50-422 Wroclaw, Poland)

\title{
OPTICAL PROPERTIES AND STABILITY OF BILAYER RUBRENE-Alq3 FILMS FABRICATED BY VACUUM DEPOSITION ${ }^{1}$
}

\section{Introduction}

In the last decade, the problem of OLED stability and long-term degradation is in the focus of organic semiconductor researches [1-3], since the operational stability of the current generation of such devices is limited by chemical reactions of the molecular components of devices. Recently, varioius approaches to the stabilization of OLEDs such as the doping of a hole transport layer, introducing a buffer layer at the hole-injecting contact, and using mixed emitting layers of hole- and electron-transporting molecules were applied [4-6]. However, the complex mechanisms of OLED degradation are still to be completely understood. Recently, we have studied the molecular structure, morphology, and photoluminescence (PL)

(C) T. GAVRILKO, V. NECHYTAYLO, L. VIDUTA, J. BARAN, 2018 of Rub layers deposited on freshly cleaved $\mathrm{KBr}(100)$ or $\mathrm{Au}(111)$ substrates by the vacuum thermal evaporation. Additionally, the two-component vacuumdeposited (VD) Rub-tetracene (Tc) films were studied. Special attention was paid to the susceptibility of films to the oxidation under ambient conditions. It was shown that Rub molecules in VD thin films are subjected to the strong oxidation in open air and, in the bi-layer structure, the deposited Tc layer only slightly enhances the stability of Rub to the photo-oxidation. In continuation of that research, we report on the optical and structural characterization of vacuum-deposited bilayer rubrene-Alq3 films.

1 The paper was presented at the XXIII Galyna Puchkovska International School-Seminar "Spectroscopy of Molecules and Crystals".

ISSN 2071-0194. Ukr. J. Phys. 2018. Vol. 63, No. 4 
Alq3 belongs to small organometallic complexes, which generally demonstrate good light emitting properties, but do not have good enough parameters for field effect transistors (FETs), probably because of their amorphous morphology in OLED devices. Alq3 is widely used in these devices due to its high fluorescent efficiency, relatively good electron mobility, and thermal stability [7]. Despite its low environmental stability, rubrene single crystals have demonstrated a high carrier mobility in FET devices [8], so it was assumed that the doping with rubrene could effectively help to maintain both FET and PL performances of OLED materials.

Rub was reported [9] to be used in important Alq3based OLEDs to improve their operational parameters by reducing the formation of unstable Alq3 cationic species [10]. Since the properties of the organic-organic interface to a great extent affect the performance characteristics of FET and OLED devices, the investigation of the interaction between the two organic components is of importance. In this work, we will focus on the effect of an Alq3 coverage on the VD Rub film stability and the aging rate in a simple model system consisting of a Rub film deposited by the thermal evaporation in vacuum on a fresh-cleaved $\mathrm{KBr}$ (111) or glass surface and an Alq3 cover layer deposited on this film in the same deposition environment.

\section{Materials and Experimental Methods}

\subsection{Materials}

Rubrene $\left(\mathrm{C}_{42} \mathrm{H}_{28}, \quad 5,6,11,12\right.$-tetraphenyltetracene, $\mathrm{Rub}$ ) and Alq3 (tris (8-hydroxyquinoline) aluminum, $\mathrm{C}_{27} \mathrm{H}_{18} \mathrm{~N}_{3} \mathrm{O}_{3} \mathrm{Al}$ ) of $98 \%$ purity were received from Merck and used without further purification. The Rub molecule is an aromatic molecule consisting of a Tc backbone with four additional phenyl groups. A Rub molecule can exist in two different structures known as twisted (D2) and planar (D1) isomers. The planar isomer is more stable in the crystal phase, since it favors the more dense packing of Rub molecules, while the twisted isomer is energetically more favorable for free molecules and those adsorbed on dielectric surfaces [11-12]. The chemical structure of Rub planar and twisted isomers and two possible geometrical isomers of Alq3, meridional (C1 symmetry) and facial (C3 symmetry) forms, are shown in Fig. 1.

ISSN 2071-0194. Ukr. J. Phys. 2018. Vol. 63, No. 4

\subsection{Samples preparation}

The thermal vacuum deposition of organic semiconductors is widely used for the fabrication of various organic devices including organic FETs [13-14] and OLEDs [15]. In our experiments, Rub was deposited on a freshly cleaved $\operatorname{KBr}(100)$ or glass substrate held at room temperature. In some experiments, Alq3 layers of about $20-40 \mathrm{~nm}$ thick were deposited on the Rub surface. The Rub and Alq3 molecules were sublimed from a polycrystalline powder. The deposition was carried out at a pressure of $\sim 5 \times 10^{-6}$ Torr, with a deposition temperature of $120{ }^{\circ} \mathrm{C}$ and a deposition rate of $5 \AA / \mathrm{min}$. The substrates were kept at room temperature. The thickness of the deposited Rub layers was controlled with a digital quartz balance monitor and varied from $\sim 1$ to $150 \mathrm{~nm}$.

\subsection{FTIR spectroscopy}

FTIR transmission spectra were used to examine the chemical structure and molecular orientation in the VD thin Rub and Rub-Alq3 films. The infrared spectra of the films were measured with a Bruker IFS88 FTIR spectrometer in the spectral range of 380 $4000 \mathrm{~cm}^{-1}$ at room temperature and in the temperature range $25-200{ }^{\circ} \mathrm{C}$. The spectra were recorded with $1-\mathrm{cm}^{-1}$ resolution and averaged over 64 scans to obtain the high signal-to-noise ratios. The background spectra were recorded for a bare substrate of the same film. OPUS 4.2 software package was used for the spectral data processing.

\subsection{UV-vis spectroscopy measurements}

Photoluminescence measurements of the VD Rub and Rub-Alq3 films on $\mathrm{KBr}$ or glass substrates were carried out with a LOMO MDR-32 monochromator. The spectral sensitivity of the system was previously calibrated. The samples were irradiated with a $\mathrm{Hg}$ lamp through a filter of $365 \mathrm{~nm}$. Origin 6.1 software package was used for the spectral data processing. All measurements were performed at room temperature.

\section{Results and Discussion}

\subsection{FTIR spectra and stability of the VD films}

FTIR spectroscopy can be used as a very helpful tool for the investigation of molecular interactions and the recognition of subtle structural changes in solid state compounds due to its high sensitivity and resolution. The vibrational spectra of Rub and Alq3 


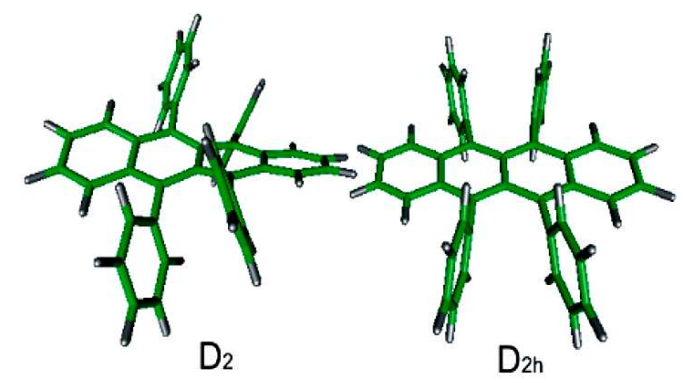

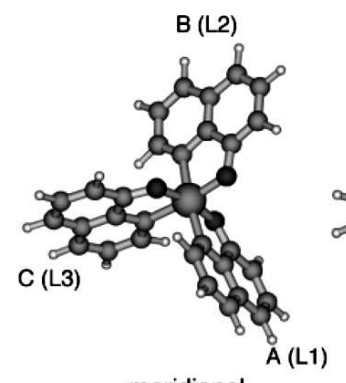

meridional

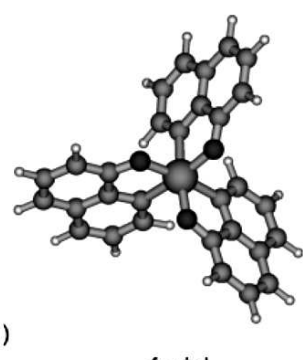

facial

Fig. 1. Molecular structures of Rub $\mathrm{D}_{2}$ and $\mathrm{D}_{2 h}$ isomers obtained from the geometry optimization at the BP86/TZVP level (a) and two geometrical isomers of Alq3 (b). Reproduced from [9] and [10], correspondingly

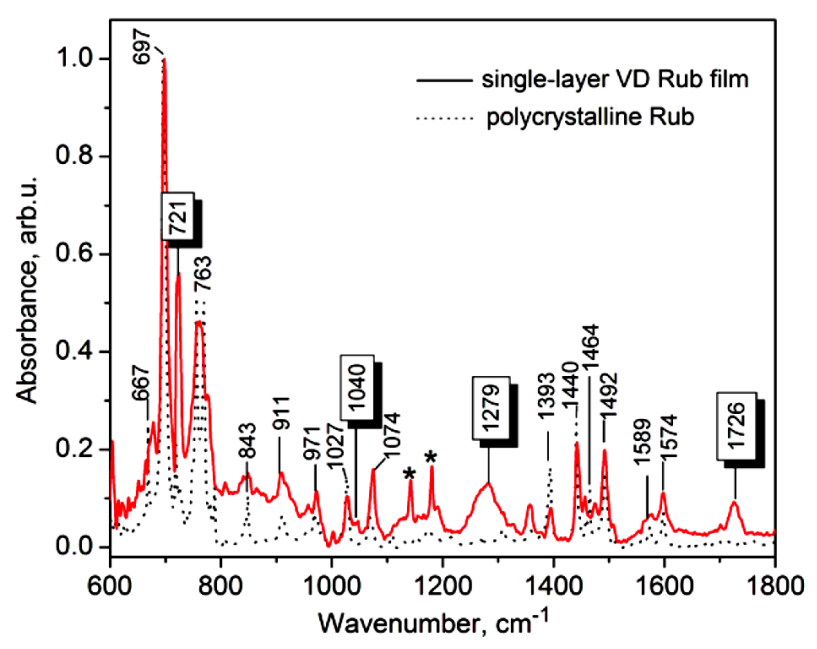

Fig. 2. FTIR absorption spectra of a single-layer VD Rub film as-deposited on $\mathrm{KBr}$ (100) surface (solid line) and bulk polycrystalline Rub (dotted line). Framed peak positions are for newly emerged bands due to the Rub film degradation in air. Asterisks indicate the absorption bands originating due to impurity centers in $\mathrm{KBr}$ windows

molecules were described elsewhere in our previous papers [16-17], and the assignment of their major absorption bands to characteristic vibrations of Rub and Alq3 functional groups has been reported in various papers using experimental spectra and theoretical calculations [18-20]. In the present paper, we use these assignments for the analysis of the FTIR spectra of our samples.

First, we checked a safe vacuum deposition of single-layer Rub in our experimental environment. The results of comparative FTIR transmission measurements of Rub polycrystalline samples and singlelayer Rub VD thin film (with a thickness of about $150 \mathrm{~nm}$ ), are shown in Fig. 2. As seen from Fig. 2, in the FTIR spectra of the VD Rub film, all major absorption bands of polycrystalline Rub (the $\mathrm{C}-\mathrm{H}$ out of plane bending bands centered at 667, 697, and $763 \mathrm{~cm}^{-1}$, bands of out-of-plane $\mathrm{CH}$ vibrations centered at 843, 911, 971, 1027, and $1074 \mathrm{~cm}^{-1}$, the middle intensity bands at 1492, 1464, 1440, and $1393 \mathrm{~cm}^{-1}$ of the acyl backbone benzene rings $\mathrm{C}-\mathrm{C}$ stretching vibrations, and the bands at 1589 and $1574 \mathrm{~cm}^{-1}$ assigned to phenol ring vibrations [21]) are observed, though most of them in the spectra of the VD film are broaden, which suggests an inhomogeneous local surrounding of the Rub molecules in the VD film due to random positions and orientations of the neighboring Rub molecules, and thus confirms an amorphous structure of the obtained film. Note that the amorphous structure of the fabricated single-layer VD films was also confirmed in our STM studies (not shown here) and reported elsewhere [16]. A similarity between the IR spectra of the VD Rub films and those of a polycrystalline sample implies the lacking of the formation of chemical bonds between Rub molecules and the substrate, confirming the safe vacuum deposition of Rub.

However, it should be noted that the FTIR spectra of as-deposited single layer Rub thin films give evidence of a chemical transformation in the film just after the vacuum deposition. This is confirmed by the emergence of new absorption bands centered at $721,1040,1279$, and $1726 \mathrm{~cm}^{-1}$. Since Rub is known to easily react with oxygen under the exposure to air with the formation of rubrene peroxide $\left(\mathrm{C}_{42} \mathrm{H}_{28} \mathrm{O}_{2}\right)$, we might expect to see new absorption bands of $\nu(\mathrm{O}-\mathrm{O})$ and $\nu(\mathrm{C}-\mathrm{O})$ stretching modes due to the Rub oxidation. In some cases, as with the formation of rubrene endoperoxide, the oxidation of acene will lead to a loss of planarity in the

ISSN 2071-0194. Ukr. J. Phys. 2018. Vol. 63, No. 4 
backbone [22]. This could lead to a distortion of the local force field and the appearance of twisted Rub isomer vibrational modes with frequencies somewhat different from those observed for a planar isomer in the vibrational spectra of a Rub crystal. This may be a cause for the new strong narrow absorption band at $723 \mathrm{~cm}^{-1}$, which could be attributed to a twisted Rub conformer $\mathrm{CH}$ wagging mode. In the vibrational spectra of peroxides, the characteristic frequency is due to the $\nu(\mathrm{O}-\mathrm{O})$ stretching mode, which gives rise to strongly polarized Raman bands about 900-700 $\mathrm{cm}^{-1}$ [23] being, however, weak in the IR absorption. According to [24], the $\nu(\mathrm{O}-\mathrm{O})$ stretching vibration interacts with other skeletal $\mathrm{C}-\mathrm{O}$ and $\mathrm{C}-\mathrm{C}$ bonds bending vibrations, and there is an extensive coupling between the $\nu(\mathrm{O}-\mathrm{O}), \nu(\mathrm{C}-\mathrm{O})$, and $\delta(\mathrm{C}-\mathrm{O}-\mathrm{O})$ modes. In addition, with the oxygen gradual permeation into the amorphous Rub film under the photo-excitation with visible light, a subsequent chemical reaction between $\mathrm{O}_{2}$ and rubrene pendant phenyl groups may take place with the formation of benzoic acid moieties. This process could be responsible for the observance of the carbonyl stretching mode at $1726 \mathrm{~cm}^{-1}$ in the FTIR spectra of the Rub film after the deposition (Fig. 2). So, the changes observed in the FTIR spectra of single-layer Rub-films probably are due to the contribution from $\nu(\mathrm{O}-\mathrm{O})$ and $\nu(\mathrm{C}-\mathrm{O})$ modes of Rub peroxide and other oxidized Rub moieties, as well as the contribution from twisted Rub isomers. These changes indicate the formation of oxidized species such as Rub endoperoxide within the amorphous Rub film under the exposure for a few minutes under ambient conditions just after the VD deposition. This observation is in compliance with previous findings of other authors [25-27].

Next, we checked the molecular composition of the as-deposited bilayer Rub-Alq3 VD films by using infrared spectroscopy to detect any changes in the absorption spectra of the films after the deposition. In Fig. 3, the room temperature FTIR transmission spectra of the obtained bilayer Rub-Alq3 films are compared with those of individual components polycrystalline Rub and Alq3. As can be seen from Fig. 3, the FTIR spectrum of the bilayer Rub-Alq3 structure shows all major absorption bands characteristic of both polycrystalline Rub (the bands centered at $697,763,911,971,1027$, and $1074 \mathrm{~cm}^{-1}$ [21]) and Alq3 (the bands centered at 647, 748, 804, and $825 \mathrm{~cm}^{-1}$ related to ring deformation/breathing

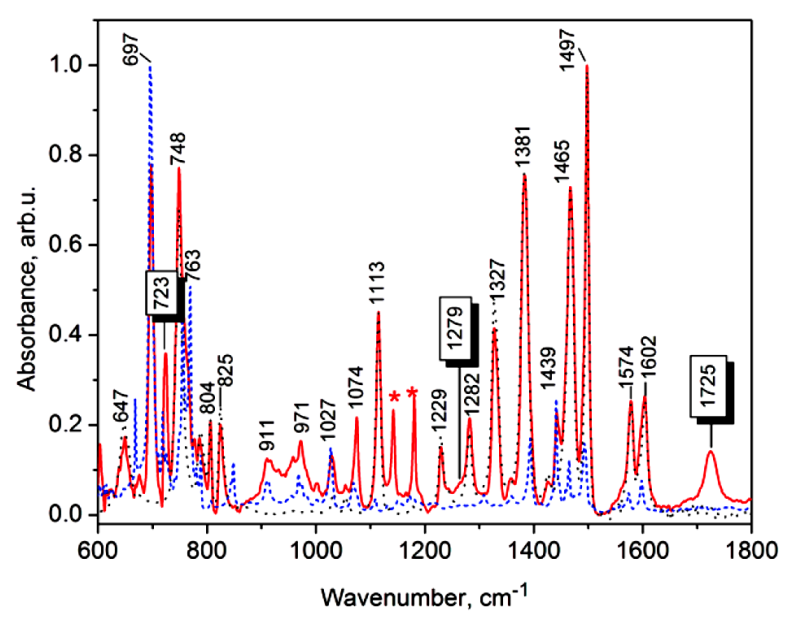

Fig. 3. FTIR absorption spectra of an as-deposited bilayer Rub-Alq3 VD film (solid line), bulk polycrystalline Rub (dashed line), and bulk polycrystalline Alq3 (dotted line). Spectra were normalized by the $647-\mathrm{cm}^{-1}$ Rub absorption. Framed peak positions mark the new $\nu(\mathrm{O}-\mathrm{O})$ and $\nu(\mathrm{C}-\mathrm{O})$ bands due to the Rub degradation in air. Asterisks indicate the absorption bands originating due to impurity centers in $\mathrm{KBr}$ windows

and $\mathrm{CH}$ wagging vibrations, the bands at 1113,1229 , 1282,1327 , and $1381 \mathrm{~cm}^{-1}$ characteristic of $\mathrm{CH}$ bending vibrations, the bands centered at 1465 and $1497 \mathrm{~cm}^{-1}$ that correspond to $\mathrm{CC} / \mathrm{CN}$ stretching + $+\mathrm{CH}$ bending vibrations, and the bands at 1579 and $1602 \mathrm{~cm}^{-1}$ originating from CC ring stretching vibrations [19, 28]).

This observation implies the lack of the formation of chemical bonds between Rub or Alq3 molecules in the film, and also that no significant changes in either Rub or Alq3 molecular structure occur after the bilayer film deposition. However, just after the deposition, the new bands centered at 1279 and $1725 \mathrm{~cm}^{-1}$ are present in the FTIR spectra of the bilayer RubAlq3 films. These new bands could be attributed to $\nu(\mathrm{O}-\mathrm{O})$ and $\nu(\mathrm{C}-\mathrm{O})$ stretching vibrations due to the formation of endoperoxide under the Rub exposure to open air like those observed in the spectra of an as-deposited single layer Rub film. At the same time, there is no sign of Alq3 chemical transformations within a few hours under the vacuum deposition. Considering that the peroxide bands are not observed in the spectra of Rub polycrystalline samples, this suggests that amorphous Rub films are oxidized much faster than polycrystalline ones. These findings well agree with observations of the Rub oxidation by other authors [22, 25, 29]. 


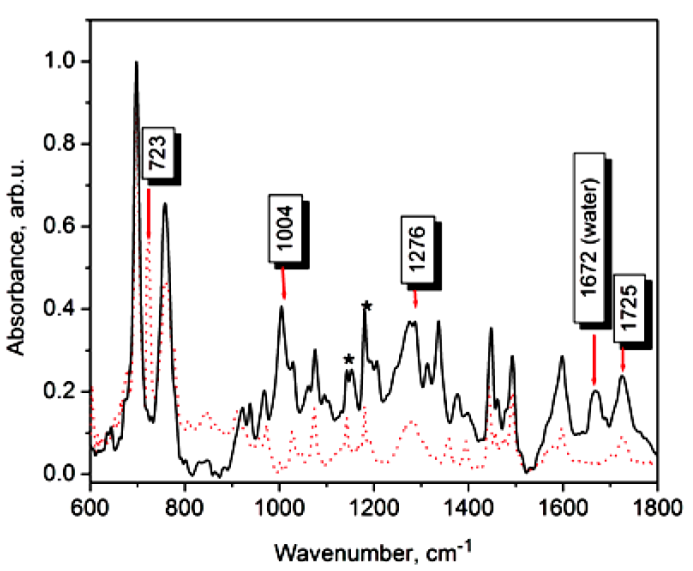

$a$

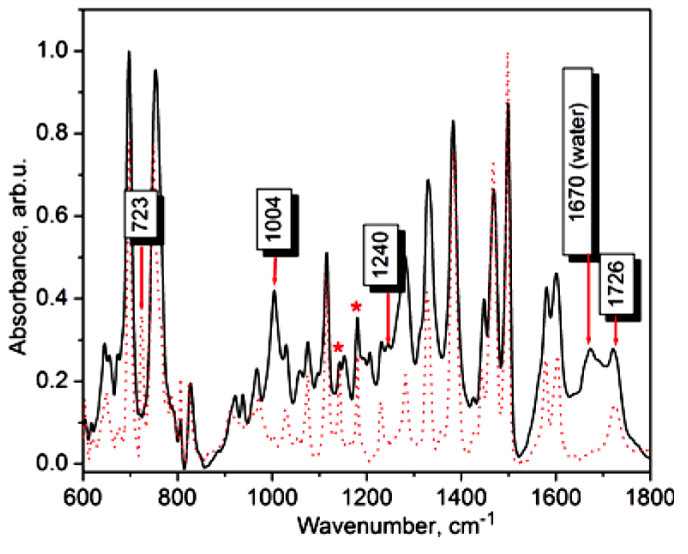

$b$

Fig. 4. FTIR absorption spectra of as-deposited (dotted line) and exposed to ambient conditions (solid line) single-layer Rub (a) and bilayer Rub-Alq3 (b) VD films. Spectra were normalized by the $647-\mathrm{cm}^{-1} \mathrm{Rub}$ absorption. Framed peak positions mark $\nu(\mathrm{O}-\mathrm{O})$ and $\nu(\mathrm{C}-\mathrm{O})$ bands due to the Rub degradation in air, and water adsorption bands. Asterisks mark the absorption bands originating due to impurity centers in $\mathrm{KBr}$ windows

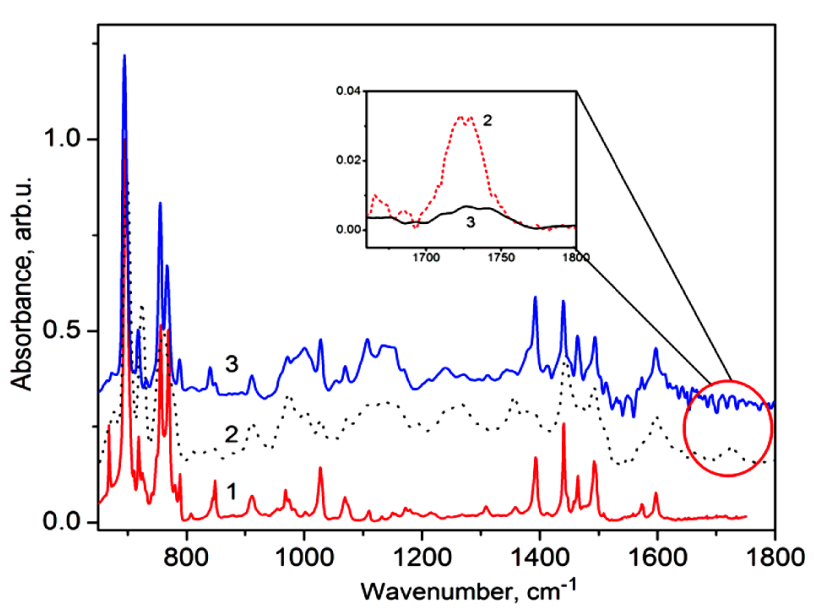

Fig. 5. Thermal treatment effect on the FTIR spectra of single-layer Rub VD film: bulk polycrystalline Rub (1); amorphous VD Rub film (2); amorphous VD Rub film annealed to $180{ }^{\circ} \mathrm{C}$ (3). All spectra are normalized by the Rub $647-\mathrm{cm}^{-1}$ absorption band and shifted vertically against each other for clarity The inset shows the magnified region of $\mathrm{C}=\mathrm{O}$ stretching vibrations

In Fig. 4, we compare the FTIR spectra of singlelayer Rub and bilayer Rub-Alq3 VD films after their light-exposure in air for 48 hours with those of asdeposited films. In particular, we note the appearance of new absorption bands at 1004, 1240, and $1726 \mathrm{~cm}^{-1}$ in both exposed films after the exposure. We consider that these new bands may be ascribed, correspondingly, to $\nu(\mathrm{O}-\mathrm{O}), \nu(\mathrm{C}-\mathrm{O})$, and
$\nu(\mathrm{C}=\mathrm{O})$ vibrations of endoperoxide species formed under the Rub interaction with oxygen under the light-exposure. The band centered at $1670 \mathrm{~cm}^{-1}$ is ascribed to bending vibrations of adsorbed water molecules. As could be seen from Fig. 4, the observed spectra are much similar, and no detectable changes were observed as for the relative intensities of the emerging $\nu(\mathrm{O}-\mathrm{O}), \nu(\mathrm{C}-\mathrm{O})$, and $\nu(\mathrm{C}=\mathrm{O})$ bands. We may ascribe this to the chemical oxidation of the very Rub in the bilayer structure, while, from the perspective of molecular structure, the number of degraded AlQ3 molecules is not substantial for their detection by FTIR spectroscopy. Therefore, we can conclude that the presence of the Alq3 cover layer has no significant effect on the Rub degradation in the VD films under the impact of ambient environment.

\subsection{Thermal treatment effect on Rub VD films}

There have been also attempts in several research groups to improve the crystallinity and stability of Rub thin films $[22,25,30]$. Here, we investigated the effect of elevated temperatures on the VD Rub film. Upon the 48-h exposure in air, the oxidized amorphous Rub film, which became colorless, was heated to $180{ }^{\circ} \mathrm{C}$ under ambient conditions. The FTIR spectra of a VD Rub film before and after heating are shown in Fig. 5. After the Rub film annealing at elevated temperatures, we observed a pristine orange-

ISSN 2071-0194. Ukr. J. Phys. 2018. Vol. 63, No. 4 


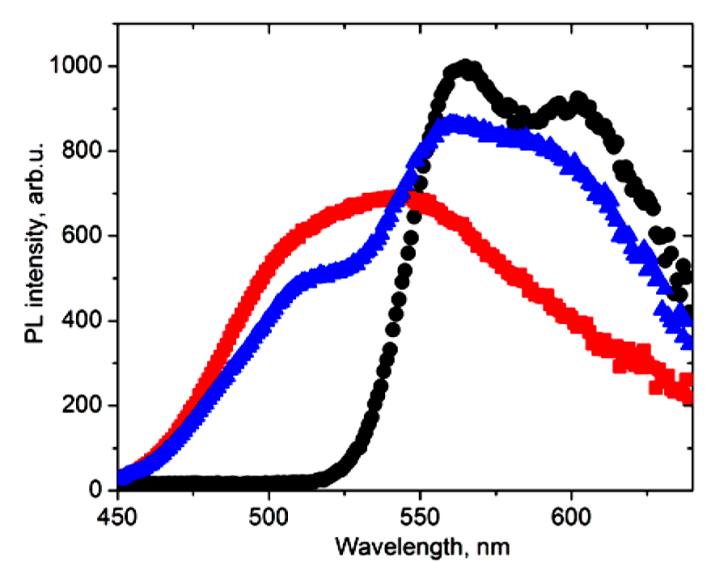

$a$

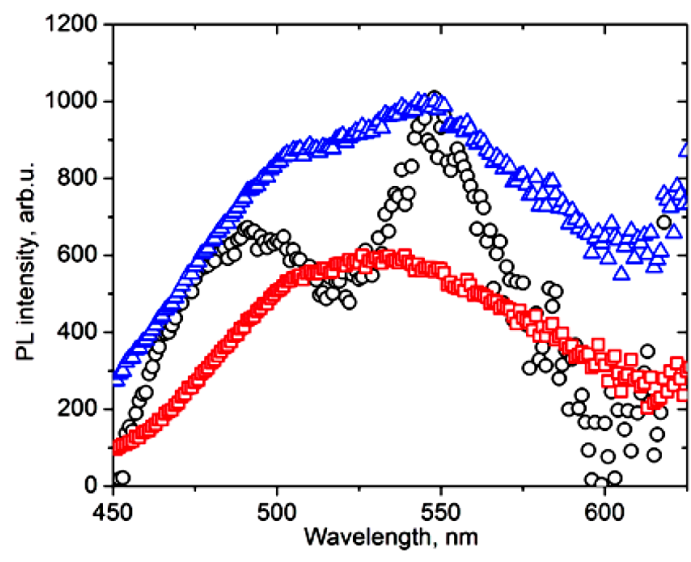

$b$

Fig. 6. PL spectra of (a) the as-prepared and (b) light-exposed single layer Rub (circles) and Alq3 (squares), as well as bilayer Rub-Alq3 (triangles) VD films.

red colored film with clearly seen crystalline grain structure. Major differences are also observed in the FTIR spectra of the Rub film after the annealing. The relative intensities of the $\nu(\mathrm{O}-\mathrm{O})$ and $\nu(\mathrm{C}-\mathrm{O})$ bands at 1004 and $1246 \mathrm{~cm}^{-1}$ due to the Rub degradation in air, as well as that of adsorbed water at $1670 \mathrm{~cm}^{-1}$ significantly decrease, thus suggesting the decomposition of endoperoxide moieties at high temperature. The bands associated with pristine Rub, such as the bands at $697,763 \mathrm{~cm}^{-1}$, become very narrow, and their relative intensity increases similarly to that observed in the spectra of polycrystalline Rub with the strongly decreased intensity of the band at $723 \mathrm{~cm}^{-1}$ characteristic of twisted Rub isomers. Therefore, we could conclude that the changes observed in the FTIR spectra of an amorphous Rub film after the annealing at temperatures $150-180{ }^{\circ} \mathrm{C}$ suggest the formation of pristine non-oxidized Rub. The observed structural changes appeared to be irreversible on the cooling.

\subsection{Photoluminescence studies}

We monitor the time evolution of the visible PL emission from the two types of fabricated VD films during the exposure under ambient conditions. Earlier, we investigated the influence of the protective layer of tetracene on the degradation rate of the photoluminescent properties of VD Rub films [16]. It was shown that such a layer slows down, but does not completely eliminate, the process. In this work, we checked the Rub degradation behavior in VD

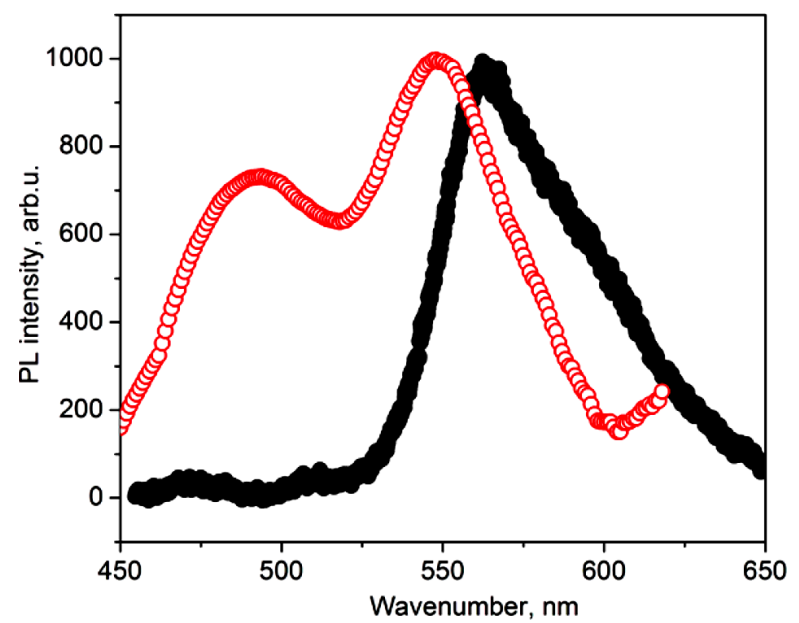

Fig. 7. PL spectra of the VD Rub film light-exposed in air for 1 month before (open circles) and after the thermal treatment (filled circles)

thin layers with $\mathrm{Alq}_{3}$ as the protective cover. Unlike tetracene, Alq3 demonstrates the intense photoluminescence. Therefore, the PL spectra of the bilayer structure contain the emission bands from the both layers. In our experiments, the PL was excited with a Hg lamp from the side of the Alq3 layer, and the PL emission spectra were recorded from the side of the substrate. Therefore, the PL emission from Alq3 was partially absorbed by the underlying Rub layer in the spectral range of Rub intrinsic absorption.

Figure 6 shows the PL spectra of single-layer VD films of Rub and Alq3 and a bilayer Rub-Alq3 VD 
film on a glass substrate before and after the light exposure in air.

The PL spectrum from the as-deposited VD Rub film consists of two strong broad emission bands centered at 565 and $610 \mathrm{~nm}$. According to the literature, the $565-\mathrm{nm}$ band corresponds to the M-polarized emission (along the short axis of a rubrene molecule), and the $610-\mathrm{nm}$ band to the L-polarized emission (along the long axis of rubrene) [31].

It can be seen from the comparison of Fig. 6, a and $b$ that the PL spectra of the VD films exposed to ambient conditions indicate the degradation of Rub both in the single- and bilayer structures. The observed overall decrease in the photoluminescence intensity is accompanied by a change in the shape of the spectrum. A new emission band appears at $485 \mathrm{~nm}$, which is characteristic of oxidized Rub species [31] and indicates the Rub oxidation in the bilayer structure. This was also confirmed by IR spectroscopy, as shown above. It is noteworthy that the band at $485 \mathrm{~nm}$ is more pronounced in the absence of a protective layer.

As was reported elsewhere [29], only twisted isomers of Rub molecules react with oxygen, while planar ones do not undergo the oxidation. This was also confirmed for the VD Rub films in our previous paper [16]. The ratio of twisted and planar isomers in the film is determined by the technological features of the preparation of samples, in particular, by the temperature of a substrate [32].

The thermal treatment of the VD Rub film lightexposed for 1 month in open air described in Subsect. 3.2 leads to the restoration of the photoluminescence spectrum of the initial film. The changes observed in the PL spectrum of the VD Rub film after the thermal treatment (Fig. 7) suggest the formation of pristine non-oxidized crystalline Rub. The nature of such a phase transition is not completely clear so far and needs the further investigation.

\section{Conclusions}

With FTIR spectroscopy, it is shown that Rub or bilayer Rub-Alq3 thin films deposited by the thermal evaporation in vacuum on freshly cleaved single crystalline $\mathrm{KBr}(100)$ or glass substrates are of amorphous structure.

Changes in the FTIR spectra of VD Rub and RubAlq3 films indicate the formation of oxidized Rub endoperoxide species under the film exposure to light under ambient conditions. These changes are less obvious for the bi-component films.

The PL degradation kinetics of the deposited Rub and Rub-Alq3 films suggests that the protective Alq3 layers are only slowing down the Rub oxidation process in the films, but do not eliminate it completely. This can be related to the diffusion of oxygen trough the Alq3 layer to the rubrene molecules.

The Rub amorphous film crystallization at elevated temperatures in open air is observed for the first time. The changes observed in the FTIR spectrum of an amorphous Rub film after the annealing suggest the crystalline phase formation of pristine nonoxidized Rub that leads to the restoration of the photoluminescence spectrum.

1. H. Aziz, Z.D. Popovic, N.-X. Hu, Ah-Mee Hor, Gu Xu. Degradation mechanism of small molecule-based organic light-emitting devices. Science 283, 1900 (1999).

2. S. Scholz, D. Kondakov, B. Lüssem, K. Leo. Degradation mechanisms and reactions in organic light-emitting devices. Chem. Rev. 115, (16) 8449 (2015).

3. M.J. Jurow, A. Bossi, P.I. Djurovich, M.E. Thompson. In situ observation of degradation by ligand substitution in small-molecule phosphorescent organic light-emitting diodes. Chem. Mater. 26 (22), 6578 (2014).

4. Z.D. Popovic, S. Xie, N. Hu, A. Hor, D. Fork, G. Anderson, C. Tripp. Life extension of organic LED's by doping of a hole transport layer. Thin Solid Films 1-2, 363 6-8 (2000).

5. Y. Hamada, T. Sano, K. Shibata, K. Kuroki. Influence of the emission site on the running durability of organic electroluminescent device. Jpn. J. Appl. Phys. 34, L824 (1995).

6. S.A. Van Slyke, C.H. Chen, C.W. Tang. Organic electroluminescent devices with improved stability. Appl. Phys. Lett. 69, 2160 (1996).

7. M.M. Shi, J.J. Lin, Y.W. Shi, M. Ouyang, M. Wang, H.Z. Chen. Achieving blue luminescence of Alq3 through the pull-push effect of the electron-withdrawing and electron-donating substituents. Mater. Chem. Phys. 115, 841 (2009).

8. V.C. Sundar, J. Zaumseil, V. Podzorov, E. Menard, R.L. Willett, T. Someya, M.E. Gershenson, J.A. Rogers. Elastomeric transistor stamps: reversible probing of charge transport in organic crystals. Science 303, 1644 (2004).

9. Z. Zhang, X. Jiang, S. Xu, T. Nagamoti, O. Omoto. The effect of rubrene as a dopant on the efficiency and stability of organic thin film electroluminescent devices. J. Phys. D 31, 32 (1998).

10. Y. Sakurai, Y. Hosoi, H. Ishii, Y. Ouchi. Study of the interaction of tris-(8-hydroxyquinoline) aluminum (Alq3) with potassium using vibrational spectroscopy: Examination of possible isomerization upon K doping. J. Appl. Phys. 96 (10), 5534 (2004).

ISSN 2071-0194. Ukr. J. Phys. 2018. Vol. 63, No. 4 
11. D. Käfer, L. Ruppel, G. Witter, C. Wöll. Role of molecular conformations in rubrene thin film growth. Phys. Rev. Lett. 95, 166602 (2005).

12. J. A. Miwa, F. Cicoira, S. Bedwani, J. Lipton-Duffin, D.F. Perepichka, A. Rochefort, F. Rosei. Self-assembly of rubrene on copper surfaces. J. Phys. Chem. C 112, 10214 (2008).

13. S.F. Nelson, Y.-Y. Lin, D.J. Gundlach, T.N. Jackson. Temperature-independent transport in high-mobility pentacene transistors. Appl. Phys. Lett. 72, 1854 (1998).

14. R.J. Chesterfield, J.C. McKeen, C.R. Newman et al. Variable temperature film and contact resistance measurements on operating $n$-channel organic thin film transistors. J. Appl. Phys. 95, 6396 (2004).

15. S.R. Forrest. The path to ubiquitous and low-cost organic electronic appliances on plastic. Nature 428, 911 (2004).

16. R. Fedorovych, T. Gavrilko, Ya. Lopatina, A. Marchenko, V. Nechytaylo, A. Senenko, L. Viduta, J. Baran. Structure, morphology, and photoluminescence of vacuum deposited rubrene thin layers. Ukr. J. Phys. 61 (6), 547 (2016).

17. T. Gavrilko, R. Fedorovich, G. Dovbeshko, A. Marchenko, A. Naumovets, V. Nechytaylo, G. Puchkovska, L. Viduta, J. Baran, H. Ratajczak. FTIR spectroscopic and STM studies of vacuum deposited aluminium (III) 8-hydroxyquinoline thin films. J. Molec. Struct. 704, 163 (2004).

18. G.P. Kushto, Y. Iizumi, J. Kido, Z.H. Kafafi. A matrixisolation spectroscopic and theoretical investigation of tris (8-hydroxyquinolinato)aluminum(III) and Tris(4-methyl8-hydroxyquinolinato)aluminum(III). J. Phys. Chem. A 104, 3670 (2000).

19. M.D. Halls, R. Aroca. Vibrational spectra and structure of tris (8-hydroxyquinoline) aluminum (III). Can. J. Chem. 76, 1730 (1998).

20. D. Esposti, M. Brinkmann, G. Ruani. The dynamics of the internal phonons tris(quinolin-8-olato) aluminum(III) in crystalline $\beta$-phase. J. Chem. Phys. 116, 798 (2002).

21. M. Kytka, L. Gisslen, A. Gerlach, U. Heinemeyer, J. Kováč, R. Scholz, F. Schreiber. Optical spectra obtained from amorphous films of rubrene: Evidence for predominance of twisted isomer. J. Chem. Phys. 130, 214507 (2009).

22. D Käfer, G. Witte. Growth of crystalline rubrene films with enhanced stability. Phys. Chem. Chem. Phys. 7, 2850 (2005).

23. C. Kloc, K.J. Tan, M.L. Toh, K.K. Zhang, Y.P. Xu, Purity of rubrene single crystals. Applied Physics A: Materials Science and Processing 95, 219 (2009).

24. L.J. Bellamy. The Infrared Spectra of Complex Molecules, Vol. 1 (Springer, 1975).

25. H. Najafov, D. Mastrogiovanni, E. Garfunkel, L.C. Feldman, V. Podzorov. Photon-assisted oxygen diffusion and oxygen-related traps in organic semiconductors. $A d v$. Mater. 23, 981 (2011).

26. K.K. Zhang, K. Tan, C. Zou, M. Wikberg, L.E. McNeil, S.G. Mhaisalkar, C. Kloc. Control of charge mobility in single-crystal rubrene through surface chemistry. Organic Electronics 11, 1928 (2010).
27. S. Uttiya, L. Raimondo, M. Campione et al. Stability to photo-oxidation of rubrene and fluorine-substituted rubrene. Synthetic Metals 161, 2603 (2012).

28. M.D. Halls, C.P. Tripp, H.B. Schlegel. Structure and infrared (IR) assignments for the OLED material: $\mathrm{N}$, N'-diphenyl-N, N'-bis (1-naphthyl)-1, 1'-biphenyl-4, 4" diamine (NPB). Phys. Chem. Chem. Phys. 3, 2131 (2001).

29. E. Fumagalli, L. Raimondo, L. Silvestri, M. Moret, A. Sassella, M. Campione. Oxidation Dynamics of epitaxial rubrene ultrathin films. Chem. Mater. 23, 3246 (2011).

30. A.J. Maliakal, J.Y.C. Chen, W.-Y. So, S. Jockusch, B. Kim, M.F. Ottaviani, A. Modelli, N.J. Turro, C. Nuckolls, A.P. Ramirez. Mechanism for oxygen enhanced photoconductivity in rubrene: Electron transfer doping. Chem. Mater. 21, 5519 (2009).

31. L. Ma, K. Zhang, C. Kloc, H. Sun, C. Soci, M.E. MichelBeyerle, G.G. Gurzadyan. Fluorescence from rubrene single crystals: Interplay of singlet fission and energy trapping. Phys. Rev. B 87, 201203(R) (2013).

32. K.Y. Lin, Y.J. Wang, K.L. Chen, C.Y. Ho, C.C. Yang, J.L. Shen, K.C. Chiu. Role of molecular conformations in rubrene polycrystalline films grown from vacuum deposition at various substrate temperatures. Scientific Reports 7, 40824 (2017).

Received 30.11.17

Т. Гаврилко, В. Нечитайло, Л. Відута, Я. Баран

ОПТИЧНІ ВЛАСТИВОСТІ

І СТАБІЛЬНІСТЬ ДВОШАРОВИХ

ТОНКИХ ПЛІВОК РУБРЕН-Alq3, ОДЕРЖАНИХ

МЕТОДОМ ВАКУУМНОГО НАПОРОШЕННЯ

Р е $з$ ю м е

Досліджено оптичні та структурні властивості двокомпонентних плівок рубрен-Alq3, одержаних методом вакуумного напорошення (BН). Відомо, що доповані рубреном активні матеріали для органічних світловипромінювальних діодів та транзисторів демонструють покращені електролюмінесцентні та електротранспортні характеристики, але практичному застосуванню таких систем перешкоджає хімічна нестабільність рубрену, що скорочує експлуатаційний термін служби відповідних пристроїв. В роботі досліджено вплив захисного шару Alq3, а також наявності різних ізомерів молекули рубрену на його хімічну стабільність у двошарових тонкоплівкових структурах. На основі експериментальних досліджень спектрів ІЧ поглинання та часової еволюції спектрів фотолюмінесценції було показано, що процес фотодеградації (утворення перекису) рубрену у плівках рубрен-Alq3 відбувається більш повільно, ніж у тонких шарах самого рубрену. Результати свідчать про те, що нанесення захисного шару Alq3 може бути засобом підвищення хімічної стійкості рубрену до фотоокислення у оптоелектронних приладах. Також нами вперше виявлено процес кристалізації аморфної плівки фотоокисленого рубрену під час її високотемпературного відпалу, який супроводжуються відновленням первісної хімічної структури молекули рубрену. 